\title{
PESANTREN FOR MIDDLE-CLASS MUSLIMS IN INDONESIA (BETWEEN RELIGIOUS COMMODIFICATION AND PIOUS NEOLIBERALISM)
}

\author{
Siti Nur Hidayah \\ Centre for Islamic Thought and Education (CITE), \\ Education Futures Unit University of South Australia \\ and State Islamic University (UIN) Sunan Kalijaga Yogyakarta \\ siti.hidayah@mymail.unisa.edu.au \\ siti.hidayah@uin-suka.ac.id
}

\begin{abstract}
Research about Islamic educational institutions, the market and the rise of the new Muslim middle-class in Indonesian society has mainly focused on schools. Its correlation with pesantren (Islamic boarding schools) as Islamic education providers has not yet been deeply portrayed. This paper aims to identify changes in pesantren management practices in relation to the growth of the Muslim middle-class and questions whether pesantren management practices intended to cater for the middle-class segment of society can be categorized as commodification or as acts of pious neoliberalism. As a preliminary examination, this paper was based on extensive literature and media research, interviews with teachers and parents in pesantren, and non-participant observation. This research highlights three different strategies developed by pesantren to respond to the growing size of the Muslim middle-class in Java, Indonesia: 'developing, 'inserting' and 'creating' new pesantren education
\end{abstract}


programs. Three models are highlighted here in three select pesantren in Java: Firstly, a pesantren established and designed to accommodate middle-class Muslims that employs an approach that is an amalgamation between religious education and international educational standards. Secondly, a well-established traditional pesantren which built new 'elite' buildings to respond to demand from middle-class Muslims. And thirdly, a pesantren that targets urban middle-class students of all ages who have limited religious knowledge and which mainly focuses on a tahfidz program (memorizing of the Qur'an) through creating a 'friendly' image of learning the Qur'an. These pesantren maintain a deeply religious curriculum similar to traditional pesantren and provide good facilities for students but charge high fees for education, and as such may connotate a commodification practice. Using Mona Atia's concept of pious neoliberalism, the writer questions whether the fusion of religious practices of any kind, commodification and adjustment to market logic, in this context, might be better understood as pious neoliberalism. In this sense, the commodification practices in the examples offered here should not always bear a pejorative meaning. While admitting that global changes have introduced new challenges to the Muslim community and in relation to Islamic education, it is hoped that this article will encourage further discussion and investigation on the subject of the changing nature of provision and management of Islamic educational institutions, in particular pesantren, in Indonesia.

Keywords: Pesantren, Middle-Class Muslim, education management, commodification, pious neoliberalism.

\section{A. Introduction}

In 2012, a prominent well established traditional pesantren in Jombang, East Java, Pesantren Darul Ulum, built new elite boarding school buildings among the existing modest buildings to cater for elite Muslim students who 
were accustomed to living in comfort. Different from other existing buildings, these new buildings named Queen and AtTin boarding school charge more expensive fees for students (Bdh, 2012). On the other hand, in Depok, West Java, in 2005, Pesantren Al Manar Azhari established a new form of the modern international standard pesantren. Besides its modern and outstanding educational facilities, this pesantren offers a mix of international and national curricula. The international curriculum is adopted from both Al-Azhar and Cambridge Universities. The fees to enrol in the pesantren are affordable only for the upper-middle-class (n.a., 2019). Slightly different in focus, in 2009, another pesantren for tahfidz developed in Yogyakarta, called Pesantren SahabatQu. This pesantren provides various tahfidz programs for school students and also for adults who want to memorize the Qur'an. These programs are open for learners who do not have a strong religious knowledge, live in urban areas, are employed, and who want to learn to memorize the Qur'an (D, 2019). Accommodating the needs of pious yet busy people, this pesantren conceptualises the Qur'an as 'friend' (sahabat).

The three different pesantren mentioned examplify how pesantren, as Islamic educational institutions, have changed their management practices in response to the rise of the Muslim middle-class in Indonesia. The rise of this segment of society has resulted in changes in peoples' Islamic educational preferences, and has triggered the development of new forms of Islamic education (Machali \& Azizah, 2018). The massive establishment of integrated Islamic schools (Hasan, 2009,2013 ) and the newly developed variant of madrasah (Islamic School), for example Insan Cendekia (Ind. Human 
Scholars/a madrasah based on science and technology), as well as madrasah based on IT and Tahfidzul Qur'an are further examples of such products. New middle-class parents tend to choose these new kinds of schools mainly because they cover the nationally standardised education curriculum essential to compete in the job market while at the same time teaching student's religion. These Islamic schools are believed to be able to shape children's character without neglecting their academic achievement (Hamdun, 2013). So far, only school institutions have been investigated in relation to the new trends. This paper shows that pesantren are also following this new trend. In providing new Islamic educational alternatives, traditional Islamic education providers are responding to the shifting choices of parents - the domination of pesantren education (Hasan, 2011) is diminishing with the proliferation of integrated Islamic schools (Jaringan Sekolah Islam Terpadu/JSIT)

As an indigenous Islamic education institution in Indonesia, the pesantren institution was established long before the colonial era (Dhofier, 2011; Van-Bruinessen, 2015). It is the root basis for Islamic education in Indonesia (Steenbrink, 1991). Initially, pesantren were mostly established in rural areas with very modest infrastructure and a traditional living environment. To illustrate, in some traditional pesantren, a room of $3 \times 4$ metres square could be occupied by 15 or more students who sleep together on the ground without mattresses. Modesty, piety, mastery of Islamic knowledge and strong bonds between pupils are among the characteristics often attributed to pesantren students. The pesantren is also believed to be the keeper of Islamic tradition 
with its teaching of the kitab kuning (classical literature of Islam). Yet, as will be discussed in this paper, contemporary shifts in the preferences of Muslims in relation to the religious education of Muslim youth have influenced the way pesantren are managed. In a world in which educational achievement is promised to lead to a better future, to remain competitive and accommodate market choices pesantren have had to adapt, through the adoption of modern approaches to education.

As a preliminary investigation, this paper aims to identify the practice of accommodation and the transformations incorporated by pesantren through their educational institutions in response to changes in consumer demand. Two presumptions that are open for debate have emerged. Firstly, the practices implemented imply religious commodification, where Islamic educational institutions utilise Islamic education based on the pesantren system, as a commodity, by marrying it with the modern system, then sell their product at a high cost to Muslim consumers (Kitiarsa, 2008). Secondly, it implies the integration of good quality Islamic education using market logic, referred to as neoliberal Islamism or pious neoliberalism. Mona Atia's (2013) term 'pious neoliberalism', as practice, represents the compatibility between business and religious piety, where religion and economics interact in the contemporary context with the principles of productivity and rationality.

While the concept of religious commodification to a certain extent represents a pejorative term because it commercializes religion for material benefit, pious neoliberalism on the other hand indicates the fusion of religiosity, economics, profit, and spirituality (Atia, 2013). I hypothesise that current trends 
in the development of pesantren education is moving from commodification to pious neoliberalism. Even though the practice implies commercialization, Islamic education, as the exemplified in the modern variant of pesantren, also serves as spiritual capital for pupils (Astuti, 2017). Indeed, some people often underestimate traditional pesantren and madrasah due to low market demand for their graduates (Mohd Nor et al., 2017; Steenbrink, 1991). However, judging the high fees of modern pesantren education to be a kind of commercialization of education may not always be appropriate. This is because middle-class Muslims are assuming new identities. They have different preferences compared to the older generation, they are knowledgeable, economically secure, trendy, and socially independent (Yuswohadi \& Gani, 2015), and it these factors which need to be accounted for by religious education providers.

\section{B. Research Methods}

This article reports the preliminary examination of the writer's qualitative research study of three pesantren in Java, Indonesia, that cater for 'middle-class' and well off people through the development of educational programs, curricula and facilities. Of the many pesantren institutions that might have similar practices, the three pesantren in this study were chosen because of the following considerations: (1). Both pesantren SahabatQu and Al-Manar Azhari state explicitly that they were established to respond to the burgeoning Islamic middle-class in urban areas. The founder of SahabatQu pesantren stated as such in the mission statement for the pesantren, while the pesantren Al-Manar Azhari stated as 
such on official Nahdhatul Ulama' (NU) ${ }^{1}$ news websites. (2). The Darul Ulum Pesantren in Jombang was chosen because of its unique approach in developing such a facility while maintaining its prominence as a leading traditional pesantren from which numerous renowned ulama (Muslim scholars) have graduated.

The data was gathered through an extensive literature and media search, interviews with the teachers (two teachers from each pesantren), one parent from Darul Ulum pesantren and through non-participant observation. The interviews were conducted in July and September 2019. Data on the Al Manar Azhari pesantren, however, was mainly based on the literature and popular media. It must be mentioned that due to the Covid-19 pandemic, the depth of data exploration was limited. Despite this, conclusions regarding the shifting practices in pesantren management can be drawn, particularly in light of the theoretical lenses referred in this article. All data collected was categorized, interpreted and analysed using a qualitative approach (Cohen et al., 2007)

\section{Discussion}

\section{New Middle-Class Muslim Preferences in Education}

Since the 1990s, a new middle-class society has arisen in Indonesia. The development of this segment of society was influenced by the economic stability of

${ }^{1}$ Nahdhatul Ulama (NU) is the largest Islamic organization in Indonesia, and in the world. Its member constitutes around 90 million in 2019. NU was established in 1926 and also is a charitable body funding schools and hospitals as well as organizing communities to help alleviate poverty. 
Indonesia during the period 2001-2010 (Ridho, 2017). This category includes professionals, reformists, lawyers, political and cultural figures, technocrats, NGO activists, and Muslim preachers (Machasin, 1993; Robison, 1993, 1996). Even though it is not simple to define this new class of society, the discourse about the definition of the middle-class in Marxian political and economic analysis of the Indonesian context has been discussed extensively in Heryanto's introduction to Politik Kelas Menengah Indonesia (The Politics of Middle Class Indonesia; Tanter and Young (1993). The category of class in this sense diverse from the capitalistic categorization, however, some problematic views occurred. Robison (1993, p. 142) uses the Weberian concept to identify welfare, income and status as determinant factors in the analyse of class structure. He asserts that middle-class people are "those who share an extensive scope of social ideologies with the bourgeoise, whether conservative or liberal and share dependency of employment and salary with the proletariat".

Some aspects that are often stressed in relation to the middle-class standard of living pertain to high levels of consumption, their emphasis on leisure, and the most important point is their excessive concern for education as a means to secure their position and wealth (Robison, 1996). Middle-class communities tend to like economic protectionism, are willing to accept greater state power and practise handicapped democratic patronage. In Indonesia, this movement has triggered the development of local government autonomy, democratic media, Islamic conservatism, and new forms of corruption and communal conflict (Van Klinken \& Berenshcot, 2016). 
The size of the middle-class in Indonesia has increased steadily since the fall of Suharto's New Order regime (1966-1998) from $25 \%$ in 1999 to $57 \%$ in 2012, and to about 66,31\% in 2016 (Purwadi \& Hasanuddin, 2017). This proportion was measured using the Asian Development Bank categorization of daily spending per capita in Indonesian society. The lower segment of the middle class spent $\$ 2$ to $\$ 4$ a day, the middle segment spent $\$ 6$ to $\$ 10$, and for the upper-middle class it was $\$ 10$ to $\$ 20$ per day. Among the middle-class demographic, the Muslim middle-class accounts for the greatest proportion since $87 \%$ of Indonesians are Muslim. While earning a greater income, and having higher educational levels, middle-class Muslims are not concerned merely with 'material' things. It may be said that in general they engage in a lifestyle that is compatible with shari'a (Prasetyo, 2016). There are at least five phenomena that culturally represent the growing number of middle-class Muslims - these are: the increased wearing of the jilbab among females, the emergence of popular religious songs, the formation of ICMI (Indonesian Association of Muslim Intellectuals) through the expansion of educated santris (students who learn in Pesantren), the establishment of modern Islamic media, and the rapidly increasing number of elite sermons (Hasbullah, 2000). ICMI in particular has a strong influence on the formation of the Muslim middle class in Indonesia (Rahman \& Hazis, 2018).

Similar to the general definition of the middle-class society, the Muslim middle-class has also some tendencies for consumption and leisure but they connect the tendency 
to Islamic principles (Rakhmani, 2016). Considering the skills and purchasing ability of this community, the industrial capital and the state are increasingly accommodating this new social force. In the economic field, shari'a banks, which incorporate spirituality and the market, have proliferated to cater for the demand from Muslim customers. However, the practice of shari'a banking tends to simplify Islam as a material procession rather than spiritual pursuit (Utama, 2012). In this way, Islam has been commodified (Fealy \& White, 2008; Kitiarsa, 2008), in the sense that Islamic products are not genuinely shaped to honour religious practice and sentiment, but rather, are more profit-driven (Hasan, 2011). The commodification of religion as an aspect of business practice brought about a shifting understanding of religious identity among Muslims. The dimensions of religiosity and business become blurred, with the practice of religiosity trapped within its formalistic symbolic aspects yet significantly (Husna, 2018) shifting from the substantial to the material (Arizal, 2016).

The Muslim middle-class perform various aspects of Islam in their daily life, such as the trend of wearing modern and stylish hijabs among female Muslims, and popular celebrities. These females realize the importance of religious values in their daily practices and are more open-minded to the development of global fashion while practising Islam (Yuswohadi et al., 2015). In contrast to the hypothesis posed by Crabtree (2010) that the more prosperous a country, the more secular it becomes, in the Indonesian context, the more prosperous a Muslim 
becomes, the more religious he/she becomes (Yuswohadi \& Gani, 2015). In relation to this last point, some critics suggest that to some extent the latter category of people are trapped in the symbolic aspect of Islam (Hasan, 2011; Husna, 2018). Examples of these contemporary symbolic aspects of Islam include the significant increase in the use of the hijab, the trend in umrah tourism as a religious vacation, the proliferation of religious sermons in cities and on television, the emergence of Islamic themed novels and films, halal foods and cosmetics, as well as the desire among increasing numbers of middle class parents to send their children to Islamic schools regardless of the costs.

Azra (2008) highlights that different from the parents during the New Order era who preferred to send their children to public schools, the emergence of the Muslim middle-class has resulted in a shift in preference towards religious-based schools (Hamdun, 2013; Machali, 2018; Suyatno, 2015). This tendency was fuelled by parental anxiety toward delinquency among youth (Fatchurochman, 2012), due to parents' inability to provide moral education at home because they were busy with their career (Yuswohadi \& Gani, 2015). As Bryner (2013) puts it, the development of integrated Islamic schools was due to the amalgamation of parents' aspirations and anxieties regarding education, wealth, morality and corruption. The schools provide a longer school day, solid academic training and a vigorous curriculum on Islamic morals and values. The five pillars of Islamic education that underpin the ethos behind this kind of school are: the curriculum is central and integrated 
into Islamic values, teachers employ a learning by doing approach, teaching and learning activities emphasize habit formation, teachers model exemplary behaviour for Muslims, and provide full-day schooling (Suyatno, 2015).

Since their initiation in the 1990s, the number of Integrated Islamic Schools (JSIT in Indonesian) has grown to more than 10.000 schools including kindergartens, and primary, junior and senior high schools throughout Indonesia in two decades later (Hisyam, 2012). The International Islamic school is a new variant of Islamic Schooling in Indonesia developed in response to global demand. The growing number of this new variant of Islamic schooling was partly due to the education decentralization policy in Indonesia (Raihani, 2012). Integrated Islamic schools, however, serve as the intersection of the Islamic movement, Islamic education, and the middle class (Bryner, 2013).

Abundant research has addressed the subject of Islamic school in Indonesia. These studies, however, failed to include modern 'elite' pesantren in the discussion of the Muslim middle class and Islamic education. This might be due to their relatively recent proliferation as a new form of pesantren in the new millennium. This paper tries to fill that research gap by considering the complex fusion of Islamic education, middle-class way of life, global demand for competition, neoliberalism and piety in the management of pesantren. 


\section{Pesantren for Middle-Class Muslim in Indonesia}

Pesantren originally comes from the word santri (pesantren pupils) with the prefix 'pe' and suffix 'an' which means a place for santri (Dhofier, 2011). He argues that the term santri is believed to be derived from an Indian word, 'sashtri', meaning a person who understands holy books of Hindu, or a scholar mastering the holy books of Hinduism. The concept of pesantren is a local Indonesian tradition (Van-Bruinessen, 2015). According to Dhofier (2011), before the 1960s, the centres of pesantren education in Indonesia were well known as pondok that might be taken from Arabic word funduq that means hotel as the pondok pesantren are boarding schools for santris or residences made from bamboo where santri live while studying away from home. For the majority of people, a pesantren is understood as a boarding school where santri learn about Islamic teachings and heritage through Arabic scripts known as kitab kuning (classical Islamic literature).

The role of pesantren has been pivotal in the provision of Islamic education since long before the state established formal education for villagers (Steenbrink, 1991). Pesantren institutions are recognized as a typically Malay-Nusantara religious educational institution. It grows rapidly throughout the country, especially in the rural areas of the north coast of Java and recently have also been developed in urban areas as well. In 2008, the number of pesantren in Indonesia was 14.067 with a total of 3,149, 374 students. In 2014, the number of pesantren had grown significantly to 27.290: a growth 
rate of 48.45 per cent over a six year period. Whereas, the total number of students also rose to $3,654,096$ people. Further, in 2008 the number of pesantren which solely taught the yellow book was around 8,000, and by 2014 this number has reached 13.336 (Hadi et al., 2016).

There are countless studies about pesantren in their various aspects (Dhofier, 2011; Hidayah \& Arifi, 2017; Srimulyani, 2012; Van-Bruinessen, 2015). However, none of them have focused on pesantren that is developed to cater for middle-class Muslim in Indonesia. Past research highlights at least two types of pesantren: pesantren salafi (traditional pesantren) and pesantren khalafi (modern pesantren) (Dhofier, 2011). Even though not all modern pesantren cater for the middle classes, middle-class pesantren are mostly managed using modern education management systems. The changes in pesantren management are essential to assuring the existence of these institutions in the context of modernization and secularization (Azra, 2002). In the example of another Muslim country, Turkey, the policy of Ma'arif Umumiye Nizamnamesi (Islamic Public General Schools) has resulted in the integration of the European education system which was then followed up with Mustafa Kemal Attaturk's policy of removing the medresse system by transforming them into public schools (Azra, 2002). In Indonesia, historically the Islamic education system has been transformed and negotiated into various forms of educational institutions such as pesantren, madrasah (Islamic non-residential schools), integrated Islamic schools, international Islamic schools and more recently incorporating the international pesantren education system. 
From my preliminary investigation, there are at least three variants of these institutions. Firstly, those pesantren that were established specifically to cater to middle-class Muslims. Here I draw on Pesantren Al Manar Azhari as an example. Secondly, those wellestablished traditional pesantren which have added new 'elite' buildings to respond to demand from middle-class Muslims, exemplified in Pesantren Darul Ulum. Thirdly, pesantren that specifically focus on tahfidz al-Qur'an, which have developed in urban areas, that not only accommodate students of school-age but also adults who want to memorize the Qur'an. This latest model of pesantren is represented by Pesantren SahabatQu.

In the following, a brief profile of the pesantren is presented:

\section{a. Pesantren Al-Manar Azhari}

Pesantren Al Manar Azhari was established in 2005 in Depok, West Java, by KH Manarul Hidayat. Formerly (since 1992), this pesantren was an Islamic school named Nurul Hidayah set up by the Al Mahbubiyah foundation in the Jeruk Purut area of Jakarta. KH Manarul Hidayat is a prominent religious and public figure, a Rais Syuriah (the highest leadership position) of the Nahdhatul Ulama organization. He was educated in numerous pesantren in Java from a young age. The Kyai obtained his bachelor's degree from UIN Sunan Gunung Jati Bandung, and his masters and doctoral degrees from Universitas Negeri Jakarta. 
In 2012, he received an honorary doctorate in the field of da'wa and religious preaching from the same university (n.a., 2018).

The development of the pesantren in incorporating modern educational standards was not without reason. The Kyai believes that contemporaneously pesantren should not be solely concerned with producing ulama' (religious scholars) and kyai (religious leaders) but should also educate students to uphold the three Islamic values of 'aliman bi dinihi (understanding and mastering religious knowledge and practising it) in which the pesantren maintains the goal to produce ulama'; 'arifan li'ashrihi (to have wisdom and knowledge regarding the current era ) which can be achieved by mastering sciences and technology; and nafi'an li umatihi (to demonstrate strong motivation to contribute significantly to society by development of akhlaqul karimah/noble character). These three values are the bedrock of Muslim societies so that they can achieve better beyond Western scientists, particularly if they able to integrate 'wahyu' (God's revelation means Qur'an) with current science and technological development (n.a., 2019).

Driven by the motivation to produce santri of excellent academic achievement, good character, and who can compete in the global world,Pesantren Al Manar Azhari combines Islamic knowledge through its 'secular' curriculum. Students' 
characters are moulded in an around the clock education system which encompasses all activities within the boarding school. Besides tahfidz alQur'an, foreign languages, and reading the Kitab Kuning, the students are also taught about how to use digital technologies. During their study, it is common in this pesantren that students develop their own blogs and media content (n.a., 2019).

Accommodating the demands of the new middle-class in urban communities, the pesantren offers a curriculum that integrates the national curriculum with an Islamic curriculum adopted from Al Azhar University in Egypt which incorporates elements of the Cambridge University curriculum, in particular in relation to the sciences of maths, chemistry, physics, and biology (Niam, 2015). The pesantren offers a complete range of facilities, such as a swimming pool, laboratories, IT rooms, music room, library, and sports facilities. All bedrooms are air-conditioned and with 4-5 students per room there is ample space. Classrooms are also air conditioned and modern. The facility was mainly built to provide students with the comfort they are used to at home so that they complete their studies in the pesantren (Niam, 2015). This pesantren also pursues a 'green' profile (Setiawan, 2020). The curriculum and facilities require high fees for students that only the upper-middle class Muslim families can afford. As an illustration, junior and senior 
high school student fees are 20million rupiah for facilities, two million rupiah to cover tuition, and five million rupiah for additional annual student fees (n.a., n.a) (Niam, 2015).

\section{b. Pesantren Darul Ulum}

The Pesantren Darul Ulum was started by KH. Tamim Irsyad with the assistance of KH. Kholil in 1885 in Rejoso, Jombang, East Java. The pesantren played a significant role in the struggle for Indonesian independence. It developed classical schooling in the form of a madrasah in 1938 starting with the establishment of Madrasah Ibtidaiyah (Islamic primary school), followed by the Madrasah Mu'alimin in 1949 and a Madrasah for girls in 1954. In 1965, the pesantren opened a university called Universitas Darul Ulum affiliated to Nahdhatul Ulama, and is the centre of Tarekat Qodiriah wa Naqsabandiyah ${ }^{2}$ in Indonesia (Romly, 2013).

Pesantren Darul Ulum embraces the motto "Berotak London berhati Masjidil Haram" meaning that the students of this pesantren are taught to have critical thinking (symbolized by London) and to have their hearts close to Allah (symbolized by Mosque al Haram in Mecca). As a traditional pesantren, Darul Ulum teaches the Kitab Kuning such as Tafsir Jalalain, Matan Jurumiyah, Aqidatul

${ }^{2}$ Tarekat is basically a sufi order that begins to be introduced in Indonesia since $17^{\text {th }}$ Century for more information see Bruinessen, M. V. (1992). Tarekat Naqsabandiyah di Indonesia: survei historis, geografis, dan sosiologis. Mizan. 
Awam and many others. There are 36 boarding schools in this pesantren complex, each is managed by a different Kyai/Nyai (male/female Islamic educator) and has its own specialisations. For example, for those who want to master the Kitab Kuning, the main boarding schools are most suitable, and for those who want to memorize the Qur'an the Hidayatul Qur'an is most fitting, and so on (A, 2019). Yet, all boarding schools have the same standards and regulation (I, 2019).

In 2012, the pesantren developed a new boarding school named At-Tin or Queen al Azhar dedicated to the memory of Ibu Tien (the wife of the late President Soeharto) following a donation from the Soeharto family in acknowledgement of the close relationship between the late $\mathrm{KH} \mathrm{As}$ 'ad Umar and President Soeharto. This new boarding school was specially designed with luxurious facilities to accommodate the wishes of uppermiddle-class parents who want their children to learn in pesantren (Bdh, 2012; I, 2019). This new building revises the pejorative image of traditional pesantren as being dirty, unhygienic, slum-like boarding schools where overcrowding leads to communicable health problemsamong santri.

In terms of facilities, this new boarding school provides rooms that are designed to accommodate 4 pupils, each has a bed of their own, showers are used instead of buckets for bathing to reduce accumulation of waste water and prevent diseases, 
there is free internet access, study rooms are airconditioned, there is a mushala (prayer room) and CCTV throughout the grounds to ensure security. The pesantren maintains a strong commitment to the green movement by maximizing sunlight during the daylight by opening the windows and outdoors uses a biopore system to assist water drainage after rain (Bdh, 2012). Interestingly, few students have chosen this new boarding school because one of the reasons for sending children to pesantren is to experience in living together in close proximity with others from different areas of Indonesia, and to develop self-responsibility and respect for others. (R, 2019). More pertinently, the choice to attend this pesantren was predominantly based on the reputation of the Kyais who manage certain boarding schools, rather than the facilities on offer (I, 2019; R, 2019).

The fees to enrol in this new luxurious boarding school are higher than other more traditional buildings. For the Queen boarding school for example, a student should pay an entry tuition fee of eight million rupiah which is relatively high compared to between one and three million rupiah in other boarding schools. Moreover, the monthly tuition fees in 2018 for a student in these buildings were eight hundred thousand rupiah, which is higher than the four to five hundred thousand rupiah in other buildings (R, 2019). Even though it is quite expensive for low middle- 
class people, the pesantren assured that this high standard of living would not lower the essence of the pesantren teachings for students. For example, after $4 \mathrm{pm}$ every day, all students have to follow pesantren activities in their boarding school, such as reading the Kitab Kuning, worship and other learning activities. The pesantren highlights its role as being to provide religious provision for its students (A, 2019). Pesantren institutions have to consider the growing number of middleclass Muslims who are accustomed to living in comfort. The minimal facilities of a traditional pesantren should not prevent wealthy Muslims from choosing to send their children to Pesantren. For that reason, pesantren need to cater for this new segment of Muslim society (Niam, 2015).

\section{c. Pesantren SahabatQu}

SahabatQu (Indonesian for my friend), stands for 'Sahabat Qur'an" (friend of the Qur'an) was preceded by the establishment of Rumah TahfidzQu (my tahfidz home) in 2009 in urban Deresan, Yogyakarta. During the Rumah Tahfidz period, students who wanted to memorize the Qur'an resided in homes around the Nurul Ashri mosque as opposed to in a boarding school. This pesantren tries to make the Qur'an accessible to all Muslims without fear that they have to live away from their families or places of employment (D, 2019). The pesantren was established 
by a successful culinary entrepreneur, Jody Brotosuseno, who does not have a Kyai's lineage, which is contradictory to Dhofier's genealogy of Kyai and the pesantren network (Dhofier, 2011), since it is Kyai who commonly most often found pesantren. This example, however, shows that managing a pesantren and teaching in a pesantren can be done separately. Those who are assumed to have less mastery of Islamic branches of knowledge can still possibly manage a pesantren.

Jody Brotosuseno aims to create the image that the pesantren is a welcoming place where Muslims can learn the Qur'an. In developing this pesantren he collaborates with KH. Yusuf Mansur (a popular Indonesian ustadz). Their intention is to increase the number of hafidz and hafidzah graduates (men and women who memorize the Qur'an). Initially improvement of this pesantren was supported by three ustadz (religious teachers). ;ustadz Afifudin, ustadz Abdul Manan and ustadz Suyitno. As more students joined tahfidz, people around the Nurul Ashri mosque felt more comfortable praying in the mosque and today the mosque has become a centre for Qur'anic sermons in Yogyakarta. Some scholars believe this mosque is a centre of urban sufism (Yusdani et al., 2019). Many santris, both 'mukim' (stay in the boarding school) and 'non mukim' (come to the pesantren during the program) are involved in pesantren activities (Af, 2019). 
As people's interest in memorizing the Qur'an flourished and many other Islamic schools began including tahfidz in their curricula, Pesantren SahabatQu developed into a formal Islamic education institution. In 2015, it opened a junior high school and kindergarten (TahfidzQu). Currently, this formal program is supported by various other tahfidz programs, for example, that cater to primary, junior and senior high school students, and there is also an intensive program for people of all ages who want to memorize the Qur'an. The latter programs are divided into two week intensive programs, those that run for two or three months and a two year program. This pesantren targets urban Muslims with limited religious knowledge who want to learn Qur'an to develop their piety (D, 2019).

The name SahabatQu was chosen to appeal to urban Muslim with no pesantren experience, and for those who hold the negative perception that pesantren are dirty, slum-like and scary. The name Sahabat (friend) connotes familiarity to laypeople, and the use of Qu (ku meaning my in Indonesian) is a direct appeal to the millennial generation through the playful use of gaul (sociable) language. Ustadz D asserts that the very aim of tahfidz is not how many shuras from the Qur'an can be memorized, but the strengthening of students' character and progress towards better achievement because of the Qur'an (Rosyid, 2017). 
The fees to enrol in this pesantren are quite expensive as a student has to pay about 17 million rupiah when they enrol to cover infaq (charity) for pesantren development, uniform, facilities, one year tuition, as well as health insurance. There is also an additional monthly tuition fee of 9 hundred thousand rupiah (Nurdi, 2018).

\section{Pesantren Management Between Religious Commodification and Pious Neoliberalism}

The discussion about commodification have brought about conceptual and methodological orientation (Kitiarsa, 2008). Religious commodification does not aim at producing a new form and movement of religiosity which contradicts the beliefs and practices of an old existing religion, but positions religion as a good which through its spiritual function becomes a commodity that is consumable by the people (Fealy \& White, 2008; Kitiarsa, 2008). In other words, religion and market forces are brought into proximity in the process of commodification and consumption of specific objects (Sinha, 2011). Through commodification, religious values are transformed. It is the transformation of value of religion as guidance for life and the normative belief in God, towards the material exchange rate through the use of religious functions to accommodate the modern need of human being (Husna, 2018).

Commodification reduces the value of religion to a material process and symbolism (Hasan, 2011; Husna, 2018). The emergence of shari'a banking, the 
hijab movement, halal consumption, shari'a hotels and Islamic education, among others, have produced a selective product using spirituality content. Islamic education is commoditized to accommodate industrial and market (societal) needs (Kitiarsa, 2008). In this context, the market is (represented by) the Indonesian Muslim middle-class. Selling Islamic education by charging high fees to accommodate middle-class market preferences can be seen to be a practice of commodifying Islam through education. However, to conclude that the three cases of pesantren management mentioned here are part of commercialization and commodification of religious practices through education requires deeper investigation given the traditional values and norms which are maintained and practised in pesantren education. I tend to agree with Greg Fealy (Fealy, 2008) who sees that commodification as a religious expression of Indonesian Muslim is:

\begin{abstract}
"due in large measure to the socio-economic, technological and cultural changes that have taken place in recent decades, driving the pursuit of moral certainty, spiritual enrichment and pietistic identity" (p.40).
\end{abstract}

The high fees and luxurious facilities provided by the pesantren might influence students' feelings and attitudes, however, the 24 hour activities in the pesantren environment together with the norms, rules and laws, shape students' characters and give them life skills, while the extensive learning of Islamic branches of knowledge, Kitab Kuning and tahfidz Qur'an contributes to enrich 
students' understanding of religion. As pesantren students mostly come from different parts of Indonesia, interaction with the heterogeneous student population enhances their capacity for tolerance of difference as well as their multicultural understandings (Baidhawy, 2010). In considering the values inculcated in pesantren related to commodification, it is worth looking closer to the concept of pious neoliberalism. Assuming that the practice of Islamic education in the pesantren coalesces with the demand of the new middle-class Muslim market, I propose that this case is part of the pious neoliberalism concept rather than purely a commodification.

The concept of pious neoliberalism was first proposed by Mona Atia (2013) with the description that the concept connotes:

"a transformation in both religious practice and modalities of capitalism. It represents new compatibility between business and piety that is not specific to any religion but rather is a result of how religion and economy interact in the contemporary moment. Pious neoliberalism produces new institutions, systems of knowledge production and subjectivities" (p. xvi).

Atia refers to pious neoliberalism as a different variant of Islamism and neoliberalism. She uses the definition of Cihan Tugal (year) about Islamism to define a project that seeks to shape the state, economy and society along Islamic lines, and neoliberalism to imply the extension of market logic into all aspect of life. Pious neoliberalism reconfigures religious practices in line with principles of economic rationality, productivity 
and privatization. Even though Atia (2013) uses the concept to investigate the practice of charity, including the management of zakat, infaq and sadaqah in Egypt, her critical perspective in problematizing the notion that anything Islamic is somehow 'counter' or 'alternate' to the 'Western' and her point that they are fluid, can to some extent be utilized to examine the practice of modern pesantren management.

The shift in pesantren management to accommodate the Muslim middle-class market by emphasizing the market logic of competition is undoubtedly the result of the interaction between religion and economy. Accommodating market logic is 'rational and pluralistic rather than emotional and exclusivist' (Fealy, 2008). The aims of such a pesantren to graduate students with a great mastery of both religious and 'secular' knowledge (science and technology) so that they able to compete in the labour market is one of the consequences of the neoliberal approach to education (Sims, 2020) and is a rational expression of Islam in adapting to social and technological change (Fealy, 2008). It is predictable that in the future this practice may bring about a new system of knowledge production within pesantren education in which the involvement of the logic of industry and market cannot be ignored.

In regard to the discussion of commodification and pious neoliberalism, all three pesantren discussed in this paper showed adaptation to the changes that have occurred in Indonesian society due to globalization, market forces, neoliberalism, and a new trend in Muslim society. All pesantren agreed to provide comfortable 
facilities to the Muslim students so that they would choose to study in a pesantren. While market logic has driven shifts in the practice of pesantren management, through charging high fees for students and lavish facilities, the capacity of pesantren to develop a deep knowledge of religion in students might be questionable. This is due to the fact that it is impossible to deny the involvement of neoliberal values in education (Sims, 2020) including in pesantren institutions.

While student accommodation facilities in pesantren may vary, the three pesantren discussed here were similar in that they all attempt to marry piety, religious education and economic logic. Pesantren Al Manar Azhari focuses on internationalizing the pesantren education system and producing graduates who are both competent in their understandings of religious knowledge and have the skills essential to compete in the fierce labour market, that is, by amalgamating religious and international education standards. On the other hand, Pesantren Darul Ulum which maintains the traditional practice and curriculum of pesantren education has accommodated the new growing middle-class market by offering new 'luxurious' buildings. These two pesantren use an inside out perspective, in which the pesantren start from existing pesantren education system then extend to accommodate the outside demands. Pesantren SahabatQu, however, uses an outside-in view by integrating a 'secular' curriculum and accommodating market demand respectively. This is by engaging prospective learners who do not have a pesantren education background, and those who are phobic or misunderstand the pesantren education system 
in the Qur'an from home. Pesantren SahabatQu does not start by establishing a formal pesantren but by providing houses for those who want to memorize the Qur'an. Indeed, it was the great enthusiasm of the community that initially encouraged the pesantren founder to formalise the education programs offered by the pesantren. The task of managing a pesantren in a rapidly changing and globalized world is challenged by the market and economic forces and demand for religious identity and values has been met by creating a 'friendly' method through whichurban middle class Muslim who have less background of religious knowledge can learn Islam through Tahfidz programs. Undeniably, the strategy of commodifying Islamic education by incorporating religiosity and economic logic in pesantren management has emerged as a 'product' of Islamic expression in Indonesia.

\section{Conclusion}

The socio-economic context, technological and industrial advancements, and market changes have influenced the way Muslims express their religiosity. Educational institutions, including pesantren, must also adapt to these changes. The burgeoning of the middle-class in Indonesia and the desire to cater to the spiritual and educational needs of Muslim students has meant that pesantren have been challenged to commodify their religious teaching by marrying religious values and piety with market logic. As we have seen through the examples demonstrated here, there are at least three ways in which pesantren accommodate these changes. These are by developing a new pesantren system that amalgamates religious and international education standards; by inserting 
new facilities within traditional pesantren to cater for middleclass students; and by creating a 'friendly' method for urban middle class students with little religious knowledge to learn Islam through Tahfidz programs. While the three programs demand high fees for educational services, it reveals that the institutions commodify religious education in their practices. Commodification in this context should not be understood as always bearing a negative meaning, but moreso is a strategy to accommodate global challenges within the practices of Islamic educational management.

While avoiding judgement of whether the development of pesantren management practices implies a positive or a negative association, the concept of pious neoliberalism helps to understand the phenomena. The emergence of the new middle class in Indonesia with the diversity of identities, tendencies and preferences of such a vast majority has triggered the shift in pesantren management. As a preliminary investigation, this research highlights the various approaches of pesantren to cater to the demand of aspiring students, both in terms of the expectations of their parents, in terms of students' need for spiritual knowledge and academic achievement. Further research is required to analyse the daily practices within pesantren, pesantren management in detail, parent attitudes, student perceptions of pesantren life, how pesantren conceptually and pragmatically respond the middle-class preferences, or a survey to the parents' aspirations or responses toward the development of this kind of pesantren for middle-class Muslim. While open to more academic debates, this paper draws attention to the emerging 'product' of the Indonesian religious market. 


\section{References}

A, K. (2019, September). Interview [Interview].

Af, U. (2019, August). Interview [Interview].

Arizal, J. (2016). Kritik Moslem Abdurrahman terhadap budaya konsumerisme kelas menengah. Jurnal Lisan Al-Hal, 8(1).

Astuti, R. D. P. (2017). Perubahan Pondok Pesantren Modern di Perkotaan: Studi Kasus Pesantren Al Adzkar, Tangerang Selatan, Banten. Masyarakat Jurnal Sosiologi, 22(2), 257-279.

Atia, M. (2013). Building a house in heaven pious neoliberalism and Islamic charity in Egypt. University of Minnesota Press.

Azra, A. (2002). Pendidikan Islam: Tradisi dan Modernisasi Menuju Milenium Baru. Logos.

Azra, A. (2008). Indonesian higher education: from public good to privatization. Journal of Asian Public Policy, 1(2), 139147. https://doi.org/10.1080/17516230802094411

Baidhawy, Z. (2010). Pendidikan multicultural untuk pengembangan masyarakat madani di Pesantren: Studi Kasus Pesantren Modern As-Salam. Jurnal Penelitian Pendidikan Agama dan Keagamaan, 8(3).

Bdh. (2012). Ponpes Darul Ulum Bangun Asrama AtTin untuk Kenang Soeharto. Detiknews. Retrieved July 15 from https://news.detik.com/berita-jawatimur/d-1936135/ponpes-darul-ulum-bangunasrama-at-tin-untuk-kenang-soeharto

Bruinessen, M. V. (1992). Tarekat Naqsabandiyah di Indonesia: survei historis, geografis, dan sosiologis. Mizan.

Bryner, K. (2013). Piety Projects: Islamic Schools for Indonesian urban middle class Columbia University]. 
Cohen, L., Manion, L., \& Morrison, K. (2007). Research Methods in Education Sixth edition. Routledge.

Crabtree, S. (2010). Religiosity Highest in World's Poorest Nations: United States is among the rich countries that buck the trend. Retrieved July 15 from https://news. gallup.com/poll/142727/religiosity-highest-worldpoorest-nations.aspx

D, U. (2019, July ). Interview [Interview]. Yogyakarta;

Dhofier, Z. (2011). Tradisi Pesantren Studi Pandangan Hidup Kyai dan Visinya Mengenai Masa Depan Indonesia. LP3ES.

Fatchurochman, N. (2012). Madrasah: Sekolah Islam Terpadu, Plus dan Unggulan. Lendean Hati Pustaka.

Fealy, G. (2008). 'Consuming Islam: Commodified Religion and Aspirational Pietism in Contemporary Indonesia. In G. Fealy \& S. White (Eds.), Expressing Islam: Religious Life and Politics in Indonesia. ISEAS.

Fealy, G., \& White, S. (2008). Expressing Islam: Religious Life and Politics in Indonesia. ISEAS.

Hadi, S., Soetarto, E., Sunito, S., \& Pandjaitan, N. K. (2016). Education Hybridization of Pesantren and its Challenges in Rural Industrialization. Jurnal Pendidikan Islam, 5(2), 261-285.

Hamdun, D. (2013). Sekolah Islam Terpadu dalam Konsepsi Kelas Menengah Atas (Studi Kasus di SDIT Ar Raihan Bantul) (Laporan Penelitian Lembaga Penelitian dan Pengembangan, Issue.

Hasan, N. (2009). Islamizing formal education integrated Islamic School and new trend in formal education institution in Indonesia. Technological University. 
Hasan, N. (2011). Islam in Provincial Indonesia: Middle Class, Lifestyle, and Democracy. Al-Jami'ah, 49(1).

Hasan, N. (2013). The making of Public Islam Piety, Democracy, and Youth in Indonesian Politics. Suka Press.

Hasbullah, M. (2000). Cultural presentation of the Muslim middle class in contemporary Indonesia. Studia Islamika: Indonesian Journal of Islamic Studies, 7(2).

Hidayah, S. N., \& Arifi, A. (2017). Women in Islamic Education Management: Learning from Pesantren Practices. ULUMUNA, 21(1).

Hisyam, U. (2012). Sepanjang Jalan Dakwah Tifatul Sembiring. PT Dharmapena Citra Media.

Husna, A. (2018). Komodifikasi agama: Pergeseran praktik bisnis dan kemunculan kelas menengah muslim. Jurnal Komunikasi Global, 2(2).

I, U. (2019, September). Interview [Interview].

Kitiarsa, P. (2008). Asia's Commodifies Sacred Canopies, in Religious Commodification in Asia: Marketing Gods. Routledge.

Machali, I. (2018). Model kepemimpinan sekolah kelas menengah muslim di Yogyakarta. EDUKASI: Jurnal Penelitian Pendidikan Agama dan Keagamaan, 16(6), 307-320.

Machali, I., \& Azizah, N. (2018). Pendidikan Islam dan kelas menengah muslim di Yogyakarta Studi di SDIT Insan Utama Yogyakarta. Intizar, 24(1).

Machasin, A. (1993). Kelas Menengah Santri: Pandangan dari dalam. In R. Tanter \& K. Young (Eds.), Politik Kelas Menengah Indonesia. LP3ES.

Mohd Nor, M. R., Senin, N., Mohd Khambali, H., \& Ab Halim, A. (2017). Survival of Islamic education in a secular state: 
the madrasah in Singapore. Journal for Multicultural Education, 11(4), 238-249.

n.a. (2018). Abi Manarul Hidayat. Retrieved July 15 from https://almanar-azhari.org/abi-manarul-hidayat/

n.a. (2019). Visi dan Misi. Retrieved June 27 from https:// almanar-azhari.org/vision-mission/

n.a. (n.a). Tour Fasilitas di SD Al Manar Azhari Islamic School. Retrieved July 15 from https://almanar-azhari. org/2021/02/tour-fasilitas-di-sd-almanar-azhariislamic-school/

Niam, M. (2015). Bidik Kelas Menengah Muslim dengan Tawaran Kualitas Internasional

NU Online. Retrieved July 15 from https://www.nu.or.id/ post/read/63709/bidik-kelas-menengah-muslimdengan-tawaran-kualitas-internasional

Nurdi, C. (2018). Metode pembelajaran Tahfidz Al-Qur'an (Studi komparasi pada Pondok Tahfidz Hamalatul Qur'an Bantul dan Pondok Tahfidzul Qur'an SahabatQu Depok Sleman) Universitas Islam Indonesia].

Prasetyo, E. (2016). SWA: Kelas menengah Islam: wajah keagamaan tanpa ide populis.

Purwadi, L., \& Hasanuddin, A. (2017). Indonesia Middle Class Muslim: Religiosity and Consumerism. ALVARA Research Center.

R, P. (2019, September). Interview [Interview].

Rahman, R., \& Hazis, F. S. (2018). ICMI and its role in the development of the middle-class Muslim communities in Indonesia in the New Order Era. Al Jami'ah: Journal of Islamic Studies, 50(2). 
Raihani. (2012). Islamic Schools and Social Justice in Indonesia: A Student Perspective. Al Jami'ah: Journal of Islamic Studies, 50(2).

Rakhmani, I. (2016). Mainstreaming Islam in Indonesia Television, identity, and the Middle Class. Palgrave.

Ridho, S. (2017). Kelas menengah muslim baru dan kontestasi wacana pluralisme di media social. Jurnal Pemikiran Sosiologi, 4(2).

Robison, R. (1993). Kelas menengah sebagai kekuatan politik di Indonesia beberapa problem analitis. In R. Tanter \& K. Young (Eds.), Politik Kelas menengah Indonesia. LP3ES.

Robison, R. (1996). The Middle Classes and the Bourgeoisies in Indonesia. In R. Robison \& D. S. G. Goodman (Eds.), The new rich in Asia: Mobile Phones, McDonald and Middle-class revolution. Routledge.

Romly, D. (2013). Buku Panduan Pondok Pesantren Darul Ulum. Yayasan PP Darul Ulum.

Rosyid, I. (2017). Model mastery learning dalam pembelajaran tahfidzul Qur'an (Studi komparasi di pondok Pesantren SahabatQu Deresan Putra Yogyakarta dan Pesantren AnNur Ngrukem Bantul UIN Sunan Kalijaga]. Yogyakarta.

Setiawan, K. (2020). LPBINU Gelar Pesantren Hijau di Al-Manar Depok. NU Online. Retrieved July 15 from https://www. nu.or.id/post/read/117566/lpbinu-gelar-pesantrenhijau-di-al-manar-depok

Sims, M. (2020). Bullshit Towers Neoliberalism and Managerialism in Universities Margaret Sims (1st, New ed. ed.). Oxford Peter Lang Ltd, International Academic Publishers. https://doi.org/10.3726/b16811 
Sinha, V.(2011). Religion and Commodification: 'Merchandizing' Diasporic Hinduism. Routledge.

Srimulyani, E. (2012). Women from traditional Islamic educational institutions in Indonesia: negotiating public spaces. Amsterdam University Press.

Steenbrink, K. A. (1991). Pesantren Madrasah Sekolah Pendidikan Islam dalam Kurun Modern. LP3ES.

Suyatno. (2015). Sekolah Dasar Islam Terpadu dalam Konsepsi Kelas Menengah Muslim Indonesia. Analisa Journal of Social Science and Religion, 22(1).

Tanter, R., \& Young, K. (1993). Politik Kelas menengah Indonesia. LP3ES.

Utama, W. S. (2012). Incorporating spirituality and market Islamic shari'a business and religious life in post-New Order Indonesia. Masyarakat: Jurnal Sosiologi, 20(2), 113-137.

Van Klinken, G., \& Berenshcot, W. (2016). In Search of Middle Indonesia Kelas Menengah di Kota-Kota Menengah. KITLV dan Yayasan Obor Indonesia.

Van-Bruinessen, M. (2015). Kitab Kuning, Pesantren dan Tarekat. Gading Publishing.

Yusdani, S., H. AH., Safitri, E., Machali, I., \& Juliansyahzen, M. I. (2019). Yogyakarta Urban Middle-Class Sufism: Economic, Political and Cultural Network. ULUMUNA, 23(2), 266-293.

Yuswohadi, \& Gani. (2015). 8 wajah kelas menengah. Gramedia. Yuswohadi, Madyani, D., Herdiansyah, I. A., \& Alim, I. (2015). Marketing to the Middle Class Muslim Kenali Perubahannya, pahami Perilakunya, Petakan Strateginya. Gramedia Pustaka Utama. 